\title{
Tradition and the Working Class, 1850-1950
}

\section{Citation}

Cohen, Lizabeth. 1992. Tradition and the working class, 1850-1950. International Labor and Working Class History 42: 82-88.

\section{Published Version}

doi:10.1017/S0147547900011248

\section{Permanent link}

http://nrs.harvard.edu/urn-3:HUL.InstRepos:4699751

\section{Terms of Use}

This article was downloaded from Harvard University's DASH repository, and is made available under the terms and conditions applicable to Other Posted Material, as set forth at http:// nrs.harvard.edu/urn-3:HUL.InstRepos:dash.current.terms-of-use\#LAA

\section{Share Your Story}

The Harvard community has made this article openly available.

Please share how this access benefits you. Submit a story.

Accessibility 


\title{
Tradition and the Working Class, 1850-1950
}

\author{
Lizabeth Cohen
}

Carnegie Mellon University

For two days, October 25-26, 1991, about forty scholars-mostly, but not exclusively, historians - sat around a conference table in the Alumni Room of the prestigious Ecole Polytechnique in Paris and discussed "Tradition and the Working Class, 1850-1950." We came from nine countries (the largest delegations were from France and the United States) to participate in the third of what has become a tradition in itself among historians of the working class, an international colloquium sponsored by ILWCH and the French social history journal, Le Mouvement social, and supported as well by the Maison des Sciences de l'Homme, CNRS, and DAGIC. The first conference took place in November 1985 on the subject of "Sociabilité of Workers and the Working Class in Comparative Perspective, 18501950" (ILWCH 29, Spring 1986). It was followed three years later, in October 1988 by "Mass Culture and the Working Class, 1914-1970" (ILWCH 29, Spring 1990). Now, six years later the same chairs, Patrick Fridenson of Le Mouvement social and Helmut Gruber of $I L W C H$, some of the same participants, and many newcomers including myself convened to explore-through concrete case studies within French, English, American, and German culture - Eric Hobsbawm's conceptualization of "the invention of tradition." Guided by a stimulating prospectus prepared by Louise Tilly (New School) and Noëlle Gérôme (CNRS), twelve papers were written to probe how working-class people, as well as political and social elites concerned with them, used what they considered "tradition" to make sense of the past, resist or justify the present, and shape the future. After almost twentyfour hours of intense talk over two days, with each intervention ably translated (and often sharpened) by Marianne Debouzy (Paris VII) and Patrick Fridenson (EHESS), most of us concluded that this construct, which at times seemed artificial or problematic, had proven fertile in prompting new analytical connections and insights into working-class culture.

We began Friday morning with the first of three thematic sessions, this one devoted to "The Working Class and Political Traditions." Marcel Van der Linden (IISG, Amsterdam) introduced papers by Geoffrey Field (SUNY/Purchase), Danielle Tartakowsky (Paris I), Michel Cadé (Perpignan), and Mary Blewett (University of Lowell) with a helpful exposition on "the imagined community," which informed Hobsbawm's "invention of tradition" for the purposes of our discussion. Van der Linden argued that whatever the group-whether British workers searching for new ways to link national and class identity during World War II (Field), French leftists struggling between 1880 and 1934 to differentiate

International Labor and Working-Class History

No. 42 , Fall 1992, pp. $82-88$

(C) 1992 by the Board of Trustees of the University of Illinois 
proletarian from republican (Tartakowsky) such as in the agricultural villages of France's "Midi Rouge" (Cadé), or Lancashire immigrants seeking to transplant traditions of popular radicalism and working-class masculinity and femininity to the textile towns of Massachusetts in the late nineteenth century (Blewett) - all set out to demarcate themselves from outsiders through symbolic rituals that reaffirmed, and sometimes redefined, their "imagined community."

Our discussion ranged widely, and despite the number of participants and the necessity for frequent translation, it flowed surprisingly coherently. Gruber pointed out that all four papers were about workers' resistance and adaptation to the efforts of capitalist societies to integrate them. Debouzy's observation that Blewett's paper suggested a sexual division of labor during strikes, with women playing the more violent role, prompted a larger discussion of how expectations for and rituals of gender were transmuted during the immigration process. Bruno Ramirez (University of Montreal) reminded us that these cultural transformations in gender roles took place within particular-and diverse - industrial contexts that also helped shape them. Christine Stansell (Princeton University) responded to Ramirez by observing that labor history is currently in tension between the particular and the general. Recent feminist labor history has shown that there may be more consistency across time and industry than we had previously assumed. The model of an increasingly male work force shaped by the exigencies of specific industries may overlook the powerful impact on workers of women at the workplace and of working-class community culture.

Gruber then asked Tartakowsky and Cadé how gender might fit into their discussion of the conflict between national and class identities. They responded that they did not have any global answers, but offered some enticing speculations about women participating in street demonstrations in twentieth-century France. Field connected this discussion to the gender dimension of working-class patriotism in England during World War II and suggested a tension between calls for women to sustain and to suspend their traditional roles in the family. Joe Trotter (Carnegie Mellon University) urged that as we consider the ways Euro-American workers worked out their class, national, and gender identities, we not forget the importance of race. That comment precipitated further discussion by Blewett, Field, and Raphael Samuel (Oxford) on how race should be inserted in the American and British contexts. After exploring "traditions" of racism, Ira Berlin (University of Maryland) brought us back to the main issue by pointing to the volatility and ambiguity of tradition, which may allow for more political instrumentality than we were acknowledging. Alain Cottereau (CNRS) went a step further and suggested that the invention of tradition may take place not only among historical actors, but also among historians and anthropologists. The paper writers responded by acknowledging the difficulty of reconstructing the mentality of historical actors, of knowing what they viewed as traditional or instrumental. The morning's discussion of the working class and political traditions ended with debate about what constitutes the "political." Mary-Jo Maynes (University of 
Minnesota) pointed out the ambiguity and multiple meanings of the term, even in these four papers.

After a break for lunch, we returned to our second thematic session on "The Appearance, Disappearance, and Reappearance of Traditions in the Working Class," which drew on three papers: Gottfried Korff's (Tübingen) on the iconography of the hand for nineteenth- and twentieth-century political movements, Bruce Levine's (University of Cincinnati) on the attempt by German and GermanAmerican workers in the mid-nineteenth century to evaluate changing conditions and to justify their responses with the language and symbols of artisanal and national traditions, and Paddy Scannell's (Polytechnic of Central London) on the way British radio reached out to new working-class audiences during World War II. Raphael Samuel approached the difficult job of introducing these three disparate papers by offering us fascinating ruminations on the problem of identifying "authentic" working-class traditions and rituals, defined as those meaningful to workers, not to sentimentalizing historians. He argued that silence can be as important as celebration in seeking evidence for what workers valued, and he pointed to the speedy dissolution of Eastern European and Soviet societies as a warning about how deceptive appearances can be. Probably because the papers ranged so widely, our discussion did as well, making it difficult to summarize.

At the end of the afternoon, session chair Stansell offered a helpful conceptualization of what she saw as a conflict in how conference participants were viewing the place of tradition in the lives of workers. Borrowing from feminist discourse, she labeled the two positions as "essentialist," stressing the continuity of tradition despite periods when submerged or diminished, and "constructionist," visualizing traditions as being created circumstantially to serve particular purposes at particular times. Although not every comment fit within this rubric, almost all of our discussion did concern the various ways workers used tradition to cope with their social, economic, and political circumstances.

If we wandered a bit in a foggy forest Friday afternoon, Ira Berlin's introduction to Saturday morning's three papers provided us with a satisfying and stimulating clarification of where we had been and where we might go. Berlin reviewed Friday's discussion and showed us some of our pitfalls: we had employed a loose definition of traditions; we had not taken seriously enough Julie Saville's (University of California, San Diego) insight that social struggles give traditions salience, not the other way around; and most importantly, we were losing our way because we were overlooking that traditions are not a conceptual end but a conceptual means. In other words, while there is a rich ethnography about tradition, it is not in itself a subject of history, but rather a way of understanding events, social struggles, cultural life, and so forth. He urged us on this second day to look for mid-level generalities by examining on-the-ground kinds of struggles where working-class people used tradition as a weapon, given the imbalance of power between themselves and more powerful superiors. The three papers before us, he suggested, offered different venues where we could see workers employing 
tradition. Gérôme's paper was an ethnographic study of the way Paris bus drivers had developed a system of representation to protect their "traditional" rights; Françoise Gribier's (CNRS) study explored the changing patterns of residence among working-class Parisians due to the intersection of life course and historical opportunities; and Larry Peterson's (CUNY Graduate Center) essay contrasted the way employers, employees, and professional photographers used photographs to depict workers and their relationship to the company town and workshops of Pullman, Illinois. Berlin added a fourth venue for our deliberation, a case of the way Christmas became a holiday for slaves on the island of Antigua in 1805. In 1799 slaves on the Samuel Martin plantation chopped their master into pieces because he denied them a Christmas holiday, a privilege they had come to expect. The authorities punished the slaves by chopping them up in turn, but six years later the legislature of Antigua, dominated by slaveholders, passed a law guaranteeing slaves a Christmas holiday. What began as the invocation of tradition took on the force of entitlement, was met with what slaves considered justifiable violence when denied, and finally became law.

Our discussion then turned to putting Berlin's challenge into practice by teasing out of the three papers what they had to tell us about the way workers invoked tradition for larger political and social ends. Field, Gruber, and I pressed Gribier to convey better what was at stake in workers' changing patterns of renting versus owning, and of residential mobility, between the 1930s and 1950s for the way the neighborhood served as a resource for political and social action. We also explored comparisons between France and other European countries. Antoine Prost (Paris I) continued the comparison and suggested that English, French, and German workers not only had different patterns of housing, but different aspirations for it that colored the kinds of demands they made through their labor organizations.

Gérôme's paper then inspired a debate among Scannell, Peterson, and Annie Fourcaut (Ecole Normal Supérieure, Fontenay) over the relationship between routine and tradition in workers' daily lives. How and when did routines become traditions? Drawing on his own work on Pullman, Peterson gave a helpful example of the workday first being organized with work periods and breaks according to routine, but when that routine was violated, workers fought to preserve it in the name of tradition. Similarly, he pointed out that industrial photography began at the Pullman Works as routine, but became tradition when the company began to use it to inculcate managerial authority at the workplace. Routine worker photography soon became ritualized in response. Prost conceptualized tradition in cases like these as "routine legitimized."

Van der Linden then shifted the discussion to the relative power of national and class traditions, a topic we had visited the previous day but which took on new significance. He suggested that antagonistic groups within nations often share common traditions that may derive from old national cultures. Stansell disagreed and invoked Samuel's example of Eastern Europe as evidence of how artificially 
constructed national boundaries can be. Within the United States, she added, the various ethnic and racial groups have forged complex relationships between American and Old World or African cultures. On behalf of carefully charting how traditions are produced and reproduced over time, Stansell argued against assuming that ancient traditions come unchanged into the present. Tartakowsky reminded us as well that the nation and the national state have different meanings in different countries, so that comparisons must be made with care. Cazals suggested that workers were capable of demonstrating multiple identities, as in a 1909 strike he had researched where they carried flags proclaiming their affiliations with nation, locality, class, and trade. Taking us back to the central issue of tradition and the working class, I urged that we not only concern ourselves with distinctions between workers and non-workers or national cultures, but that we also scrutinize tradition within the working class and recognize that even among workers tradition is negotiated-between genders and familial generations, and between militants and the rank-and-file.

Saturday afternoon culminated with a final session devoted to synthesis. Not surprisingly, we tended less to theorize or conceptualize all previous discussions and more to elaborate on unresolved themes and issues. Bella Bianco Feldman (Southeast Massachusetts State College and Brazil) expanded the notion of negotiation within working-class culture to include the way workers balanced their experiences at work, after work, and at home. She was particularly fascinated by what the home reveals about workers' "double" (and possibly triple) lives. Olivier Schwartz (Nantes) elaborated on the "private" side of tradition by drawing on his ethnographic investigations into the family lives of miners in the north of France. Not only did he agree with Feldman that we had slighted tradition within the family, but he argued that more attention to it would illuminate the oppressive and ambivalent side of working-class tradition, particularly encapsulated in rituals of domination practiced by husbands toward wives.

Taking us back to the morning's discussion, Prost reiterated that much can be learned from cross-national comparisons and pointed specifically at revelations resulting from words that cannot be translated or that have slightly different meanings in other languages. He gave examples such as "nationalized" and "mutualité" in French versus "public ownership" and "friendly societies" in English. Frantisek Svatek (Institute for Contemporary History, Praha, Czechoslovakia) pursued the comparative theme by contrasting the interrelationship of national and working-class culture in Eastern and Western Europe. Levine theorized how tradition played into class relations in Western industrial societies. Bourgeois elites, he argued, often invoked tradition to assert their continuity with a supposed consensual past even as they were challenging it; in response, workers took a defensive position, also relying on traditions similarly adjusted with an eye to present circumstances. Traditions vanish, he suggested, when conditions have changed so much as to deprive them of resonance, specifically when a particular class decides traditions are so archaic that invoking them proves more of an 
obstacle than an impulse to its own mobilization. Berlin was less sure that traditions do vanish; he argued that they are often set aside and then rediscovered. $\mathrm{He}$ also wondered if it is so easy to identify who is acting and who reacting. He preferred to see conflicts between subordinates and superordinates-over, for example, the length of the workday, holidays, and the division of labor - as pulling and tugging from both sides, "rules of the game" that are perpetually contested.

Field related Levine's discussion of the relationship between national traditions and class agendas to the particular case of twentieth-century England and suggested that a close examination of jubilees to celebrate war victories and coronations reveals that working-class people, particularly women, used these national occasions to affirm their own working-class neighborhoods. Picking up on the way traditions ebb and flow in working-class culture, Anne Monjaret (Paris $\mathrm{X}$ ) shared her research on the evolution of St. Catherine's Day, a celebration by single women not yet twenty-five that had been generalized from garment workers to all female employees and today has become less religious and more professional in character. Most recently, it has been employed by labor militants who have sought to use it in their struggle, and by feminists who have rejected it.

The issue of traditions being contested between classes and within the working class continued to elicit interest. Blewett urged that in focusing on these contests over tradition, we can see how power was constructed in the working class and how the participants themselves understood particular traditions. Cadé conveyed the value of locating moments when new traditions were invented by offering a case in which a labor organization in a small village in southern France incorporated the statue of a locally born hero-an astronomer-into its rituals to draw in the rest of the community. Trotter pointed out that despite our disagreements and confusions, a consensus was emerging that tradition has been contested by classes, genders, generations, ethnicities, and races - and that those conflicts play a central role in the appearance, disappearance, and reappearance of traditions.

By the end of the day, we had run out of only time and energy, not of engagement in what had proved to be an extremely stimulating discussion. As Gruber and Fridenson pointed out in their concluding remarks, by the second day we were functioning as a seminar that had been meeting for weeks. Certainly, the conference was not without problems. Tradition proved more meaningful to most of us as a vehicle for other questions than as a question in itself. The session topics flowed almost imperceptibly into one another, and the papers sometimes did not fit well with each other, or with the session topics. And with reference points from so many different societies, at times we spoke past, rather than to, each other. But these are minor issues when compared with the high level of intellectual exchange and the way that our greater awareness about the meaning of tradition is bound to influence our future work. I apologize if in trying to reconstruct the proceedings of this conference for $I L W C H$ readers, I have overlooked or distorted any important interventions by participants. I hope you at least have gained the flavor of what 
seemed to me-admittedly attending an international scholarly conference for the first time - to be exactly the blend of collegiality and controversy one would hope for in an international colloquium. 